\title{
Design of Mobile Application as Communication Media and Information Broadcasting for Elementary School Based on Android
}

\author{
Desi Windi SARI ${ }^{1}$, Abdul Haris DALIMUNTHE ${ }^{2}$, Nadia THEREZA ${ }^{3}$ \\ ${ }^{1,2,3}$ Sriwijaya University, Palembang, Indonesia \\ *Corresponding author: desi_windi@unsri.ac.id
}

\begin{abstract}
In elementary schools, the delivery of various kinds of information and communication between the school and parents must be very good and intense, that is because elementary school students have not been able to set their learning patterns and study schedule and sometimes they forget to convey messages from the teacher to their parents. Therefore, elementary school students must always be supervised and assisted by the school and also the parents. Currently, the media information between parents and the school is still utilizing social media. The existence of a special system of communication media and information broadcasting in elementary school is highly expected by parents and the school. By designing and building an android-based mobile application system that can be used as a medium of communication and information broadcasting between the school and parents, students are expected to facilitate and help both parties. This mobile application is designed by using a method that refers to the RAD design methodology by utilizing Ionic software, CodeIgniter as a PHP framework, system media editor using Netbean IDE and tools in system design analysis using the Kipling method $(5 \mathrm{~W}+1 \mathrm{H})$ and SOAR analysis.
\end{abstract}

Keywords: application, mobile, information, elementary school

\section{INTRODUCTION}

Elementary school is the most basic level of formal education in Indonesia after Kindergarten education. Every student must have two teachers of their lives, namely parents and teachers/homeroom teachers in their schools. When students have entered school does not mean the responsibility is entirely transferred to the teacher, the role of parents is also very important for the development of their children [1]. Therefore, communication between parents and the school/teacher must both be well-established. The proper use of technology and communication can help in the process of good communication. Information and communication technology (ICT) is a familiar thing for the community that plays an important role in the field of education [2].

At this time, information and communication technology used for communication media systems and broadcasting information between parents and the school/teacher through WhatsApp (WA) and also the liaison book. This media can not store the result of communication on the database. Likewise, with the liaison book, students sometimes forget to bring the liaison book or left behind and the liaison book is also vulnerable to damage or loss. For that reason, the author will design and build a mobile application as a communication media and information broadcasting for elementary school based on Android which is useful and facilitate communication for its users (school and parents Students). Mobile applications are designed to be a liaison medium between the school and parents, parents can find information about the school and child development at school, information on grades. So, with this mobile application, it can be expected that parents and the school can communicate well about the development and activities of their children at school so that with this mobile application parents can monitor their children's development at work or home effectively.

\section{RESEARCH METHODS}

The research method that authors use is the RAD (Rapid Application Development) research method. The workflow stage of the RAD method is shown in Figure 1 below [3].

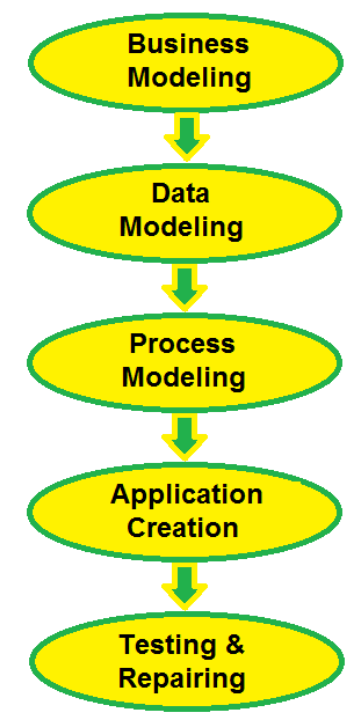

Figure 1. Stage sequence of the development method

The following table describes the processes carried out at each stage of the design method. 
Table 1. The process of each design stage

\begin{tabular}{|l|l|l|}
\hline \multicolumn{1}{|c|}{ Stages } & \multicolumn{1}{|c|}{ Processes } & \multicolumn{1}{c|}{ Results } \\
\hline $\begin{array}{l}\text { Business } \\
\text { Modeling }\end{array}$ & $\begin{array}{l}\text { Perform data collection by conducting } \\
\text { interviews with users of the system that } \\
\text { data will be analyzed by Kipling and SOAR } \\
\text { analysis method. }\end{array}$ & $\begin{array}{l}\text { Obtaining document interviews from } \\
\text { prospective users of the system. }\end{array}$ \\
\hline $\begin{array}{l}\text { Data } \\
\text { Modeling }\end{array}$ & Modeling data structures on the system. & $\begin{array}{l}\text { Results of data structure analysis on the } \\
\text { system. }\end{array}$ \\
\hline $\begin{array}{l}\text { Process } \\
\text { Modeling }\end{array}$ & $\begin{array}{l}\text { Modeling actor interaction against the } \\
\text { system. }\end{array}$ & $\begin{array}{l}\text { Design results of actor interaction } \\
\text { modeling against the system. }\end{array}$ \\
\hline $\begin{array}{l}\text { Application } \\
\text { Creation }\end{array}$ & $\begin{array}{l}\text { Determine the hardware and software } \\
\text { that will be used for developing, creating } \\
\text { databases, and coding. }\end{array}$ & $\begin{array}{l}\text { Determination of hardware and } \\
\text { software, the formation of databases, } \\
\text { and applications have been coded. }\end{array}$ \\
\hline $\begin{array}{l}\text { Testing and } \\
\text { Repairing }\end{array}$ & $\begin{array}{l}\text { Testing the application using the black } \\
\text { box testing method. }\end{array}$ & a black box testing document. \\
\hline
\end{tabular}

If all stages are done and according to the plan of achievement, the system design has been successfully designed.

\section{RESULTS AND DISCUSSION}

\section{Business Modeling}

At this stage, interviews will be conducted at the school that will use this application. The conclusions of the answers obtained from questions in interviews are:

\section{a. Question 1.}

How are information broadcasting and media communication in this elementary school? Through what media?

\section{Conclusion question 1.}

Information broadcasting and media communication used to provide information and communicate with parents are through the liaison book, WhatsApp (WA) and circular letter.

\section{b. Question 2.}

Do you think that the current media has been effective and helpful in providing information and communication to parents?

\section{Conclusion question 2.}

The current media is quite effective and has fulfilled the needs of the school to spread the information and communicate with parents.

\section{c. Question 3.}

If there is a specific application that can make it easier to convey information from school and teachers to parents, are you interested in using it?

\section{Conclusion question 3.}

The school agrees and wants to use if there is a system of broadcasting information and special communication media for intermediaries between the school and parents of students with features that can make it easier for the school to convey information and communicate with parents.

After conducting interviews, it will be identified matters relating to the system internally and externally. At the internal business modeling stage, identification of matters relating to the system internally is carried out using the help of the $5 \mathrm{~W}+1 \mathrm{H}$ Kipling method, as follows:

1. What

What systems are designed, what services and features are available in the system?

The system designed is the design of the mobile application as communication media and information broadcasting for elementary school based on android. The system with a special application as a medium of information and communication for parents with the school/teacher. This application is available features to view announcements, test scores reports, and other important information.

\section{Where}

Where this system can be used?

The system can be used anywhere as long as it is accessed to the internet network.

3. When

When this system can be used?

The system can be used at any time after the user has downloaded the application on the smartphone and logged in the user account that has been created by the admin (the school). This application can be accessed while connected to the internet network.

4. Who

Who uses this system?

Users in the mobile application system are: 
1. Teachers as an active user of the school to transmit information data, to update the information data, and reply to messages from parents. Teachers operate the system through the application on the smartphone.

2. Parent students operate the system through mobile applications such as teachers, but passive because they can only receive information data, view new information, and send messages to teachers.

5. Why

Why is this system designed in the form of applications?

Because it can facilitate to provide information from the school to the parents of students and make it easier for parents to get more precise information.

6. How

How is a mobile application as communication media and information broadcasting for elementary school based on android designed?

If viewed technically, the technology system is designed for mobile applications that can operate on Android. Data on the system will be stored in the system rendering database. The design of this system required some software, hardware and computer networks that support it.

Identify the system externally by using SOAR analysis assistance, namely Strength, Opportunities, Aspiration, Result. Following the table with the help of SOAR analysis.

Table 2. SOAR analysis

\begin{tabular}{|c|c|}
\hline Strength & Opportunities \\
\hline 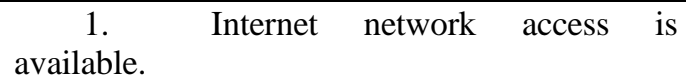 & $\begin{array}{l}\text { 1. There are no similar apps in some } \\
\text { elementary schools yet. }\end{array}$ \\
\hline $\begin{array}{l}\text { 2. Human resource experience in } \\
\text { software design and development. }\end{array}$ & $\begin{array}{l}2 . \\
\text { system. }\end{array}$ \\
\hline $\begin{array}{l}\text { 3. Users use smartphones almost } \\
\text { every time in their activities. }\end{array}$ & $\begin{array}{l}\text { 3. Parents need to get information } \\
\text { about the data on the development and activities of } \\
\text { children in schools that are more effective and } \\
\text { efficient. }\end{array}$ \\
\hline Aspiration & Result \\
\hline $\begin{array}{l}\text { 1. Easy-to-use application system. } \\
2 . \quad \text { As media information that has the } \\
\text { best information security system. } \\
\text { 3. Provide convenience to the } \\
\text { teacher/ school parties as a part of giving students } \\
\text { the activities information in elementary school to } \\
\text { parents more easily and efficiently. }\end{array}$ & $\begin{array}{l}\text { An Android mobile application system for broadcast } \\
\text { System information in the elementary school between } \\
\text { the teacher and parents. }\end{array}$ \\
\hline
\end{tabular}

\section{DATA MODELING}

At this stage, the data obtained from the business modeling phase will be done in the design of interclass interaction systems in this system by designing a diagram class structure to describe the necessary data structures. Then, the data model that has been modeled, is implemented as a database [4]. Here are the data modeling diagram images contained in the system.

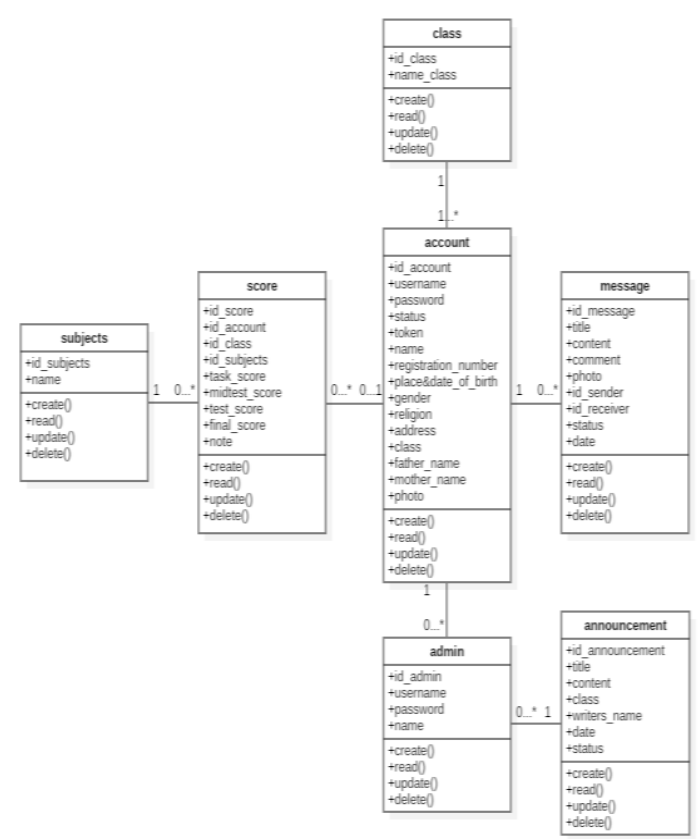

Figure 2. Data modeling diagram 


\section{PROCESS MODELING}

At this stage, it is performed to illustrate the process modeling on a system that includes the user action against the system [5]. The design of the work process stages that actors can do as application users are depicted in Figures below. There are two Figures of the teacher interaction diagram on the system in Figure 3 and also the student's parental interaction diagram of the system in Figure 4.

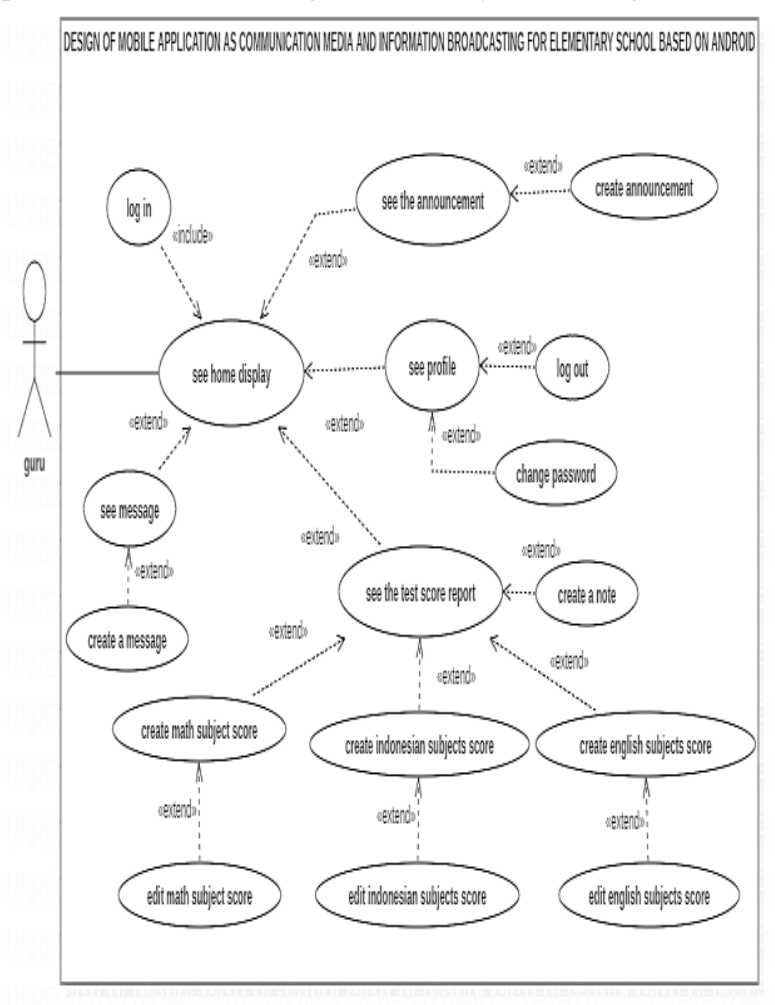

Figure 3. Diagram of interaction between teachers and systems

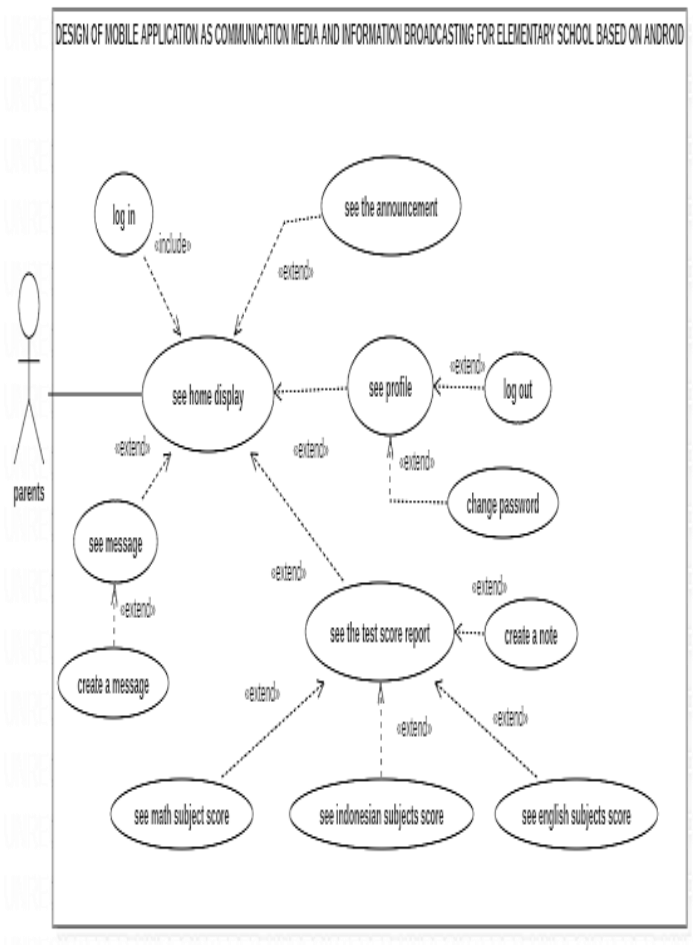

Figure 4. Parents interaction Diagram of the system

\section{APPLICATION CREATION}

This stage where the system is implemented into the application form. Stages in application creation that determines the needs of hardware and software specification, create databases, data coding.

1. Hardware Specifications

Table 3. Hardware specifications

\begin{tabular}{|c|l|c|}
\hline Hardware & \multicolumn{1}{|c|}{ Spesification } & Quantity \\
\hline Laptop & $\begin{array}{l}\text { HP, Processor Core i3-6006U, Speed 1,99 GHz, RAM 4 GB, Screen } \\
14 \text { inch, Monitor Resolution 1366 x 768 Pixels, Hardisk 500 GB }\end{array}$ & 2 \\
\hline $\begin{array}{c}\text { Smartphone } \\
\text { Android }\end{array}$ & $\begin{array}{l}\text { OS: 2.1 Lollipop } \\
\text { Internal Memory : 16GB, 2GB RAM }\end{array}$ & 2 \\
\hline
\end{tabular}

2. Software Specifications

Table 4. Software specifications

\begin{tabular}{|l|l|}
\hline \multicolumn{1}{|c|}{ Software } & \multicolumn{1}{c|}{ Software Advantages } \\
\hline $\begin{array}{l}\text { Visual Studio Code and } \\
\text { Netbeans. }\end{array}$ & $\begin{array}{l}\text { A program or software that serves as the place of the editors in conducting } \\
\text { the coding process. }\end{array}$ \\
\hline $\begin{array}{l}\text { Web Browser: } \\
\text { Google Chrome }\end{array}$ & $\begin{array}{l}\text { A program or software used as a simulated media for the results of the } \\
\text { application and Web applications to be generated. }\end{array}$ \\
\hline
\end{tabular}




\begin{tabular}{|l|l|}
\hline XAMPP & $\begin{array}{l}\text { As a localhost that only runs on one device to test the website and } \\
\text { applications before it is placed on the first hosting and in the creation of } \\
\text { databases. }\end{array}$ \\
\hline $\begin{array}{l}\text { Programming } \\
\text { language: }\end{array}$ & It is a set of syntax and semantic rules used to define computer programs. \\
$\begin{array}{l}\text { HTML5, PHP, CSS3, } \\
\text { MySQL, JavaScript. }\end{array}$ & $\begin{array}{l}\text { Software to facilitate the programmers create applications or Web content } \\
\text { is a variety of functions, plugins, and concepts so that it forms a particular } \\
\text { system. Using the framework, an application will be neatly organized and } \\
\text { structured. }\end{array}$ \\
\hline $\begin{array}{l}\text { Framework: } \\
\text { AngularJS, Ionic 2 }\end{array}$ & \multicolumn{2}{|l}{ Igniter 3, }
\end{tabular}

3. Create the Database

Creating a database previously created based on the diagram class at the data modeling stage, then performed the implementation according to the selected DataBase Management System (DBMS). In creating a database of information and communication systems in this elementary school, authors use phpMyAdmin to manage MySQL databases.

\section{Coding}

This is a process that needs special attention from the planning phase. Coding is the stage of translating the logic requirements of the diagrams into a programming language both letters, numbers, and symbols that make up the program so that it produces the system in real form [6]. Here is an example coding for the home page on the system.

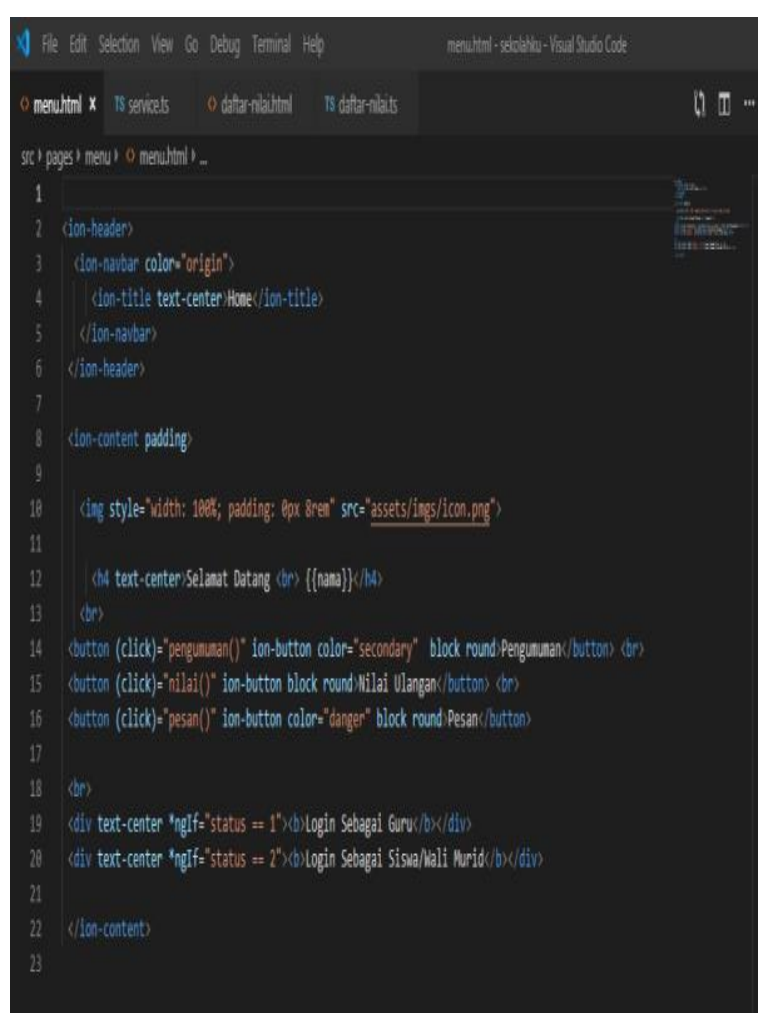

Figure 5. Coding of Home Page
The display of coding of the home page in Figure 5 above can be seen in Figure 6 below.

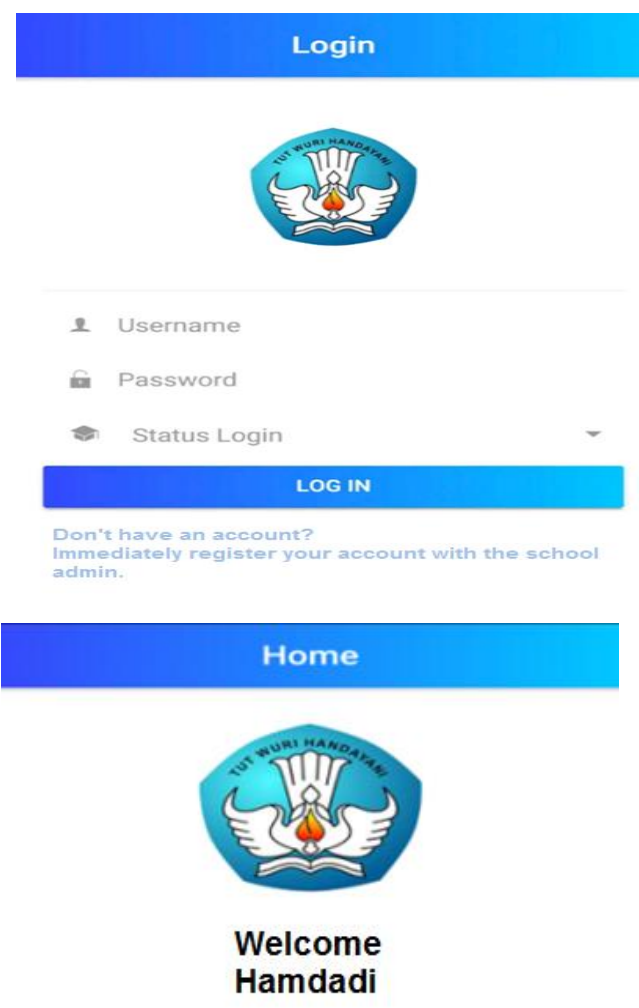

ANNOUNCEMENT

TEST SCORES

MESSAGE

Login as a teacher

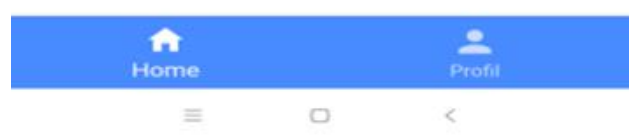

Figure 6. Display of Login Page and Home Page 


\section{TESTING AND REPAIRING}

The program completes, the testing process is carried out on the program whether there are errors or not. The testing of the mobile application design system as a medium of communication and information dissemination for
Android-based elementary schools is carried out in 2 stages, namely the Black Box Testing method that focuses on application functionality and the System Testing Questionnaire [7].

Table 5. Black box testing for functional making announcement

\begin{tabular}{|c|c|c|c|}
\hline Scenario & Test Case & Expectation & Hasil \\
\hline $\begin{array}{l}\text { Populate data details on the page } \\
\text { making announcements to be } \\
\text { published on the mobile } \\
\text { application. But empty the } \\
\text { announcement title field. }\end{array}$ & $\begin{array}{l}\text { - Empty the announcement } \\
\text { title } \\
\text { - Write down the } \\
\text { announcement content } \\
\text { - Attach Images } \\
\text { - Select recipients } \\
\text { - Click Upload }\end{array}$ & $\begin{array}{l}\text { The system will deny } \\
\text { access to make } \\
\text { announcements and display } \\
\text { results to complement the } \\
\text { messages to be uploaded. }\end{array}$ & Valid \\
\hline $\begin{array}{l}\text { Populate data details on the } \\
\text { page making announcements to } \\
\text { be published on the mobile } \\
\text { application. But empty the } \\
\text { Content Field/description } \\
\text { announcement }\end{array}$ & 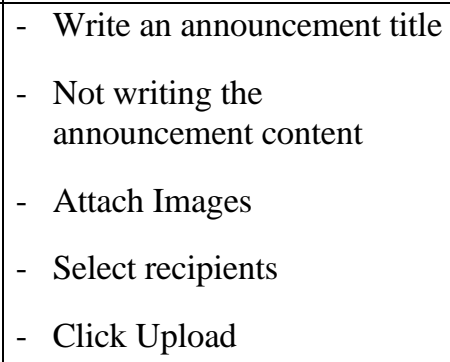 & $\begin{array}{l}\text { The system will deny } \\
\text { access to make } \\
\text { announcements and display } \\
\text { results to complement the } \\
\text { messages to be uploaded. }\end{array}$ & Valid \\
\hline $\begin{array}{l}\text { Populate data details on the } \\
\text { page making announcements to } \\
\text { be published on the mobile } \\
\text { application. But do not choose } \\
\text { the recipient announcement }\end{array}$ & $\begin{array}{l}\text { - Write an announcement title } \\
\text { - } \text { Write the announcement } \\
\text { content } \\
\text { - } \text { Attaching images } \\
\text { - } \\
\text { Not selecting recipients } \\
\text { - } \text { Click Upload }\end{array}$ & $\begin{array}{l}\text { The system will deny } \\
\text { access to make } \\
\text { announcements and display } \\
\text { results to complement the } \\
\text { messages to be uploaded. }\end{array}$ & Valid \\
\hline $\begin{array}{l}\text { Filling the entire details on the } \\
\text { page makes the announcement } \\
\text { correctly to be published on the } \\
\text { mobile application. }\end{array}$ & $\begin{array}{l}\text { - Write an announcement title } \\
\text { - } \text { Write the announcement } \\
\text { content } \\
\text { - } \text { Attaching images } \\
\text { - } \text { Select a recipient } \\
\text { - } \text { Click Upload }\end{array}$ & $\begin{array}{l}\text { The system will receive } \\
\text { access to upload } \\
\text { announcements and display } \\
\text { the results of } \\
\text { announcements that have } \\
\text { been uploaded } \\
\text { successfully. }\end{array}$ & Valid \\
\hline
\end{tabular}

After conducting the testing stage then it can be known that the design of mobile applications as a medium of communication and information broadcasting for elementary school based on android is worthy to publish so it can be used and useful for its users. This application is suitable for use, a survey was conducted on 3 elementary schools in Palembang city. The survey is to ask for opinions about the function, design, possibility of implementing this application in the school. The elementary schools polled were SD Az-Zahra, SD Al-Furqon, and SD Bina Ilmi. The following table summarizes the results of the survey. 
Table 6. Opinion survey results regarding the application.

\begin{tabular}{|c|c|c|c|}
\hline & SD Az-Zahra & SD Al-Furqon & SD Bina Ilmi \\
\hline Function & Very helpful & Very helpful & Very helpful \\
\hline Design & $\begin{array}{l}\text { Easy to } \\
\text { understand }\end{array}$ & $\begin{array}{l}\text { Easy to } \\
\text { understand }\end{array}$ & $\begin{array}{l}\text { Easy to } \\
\text { understand }\end{array}$ \\
\hline $\begin{array}{c}\text { Possible } \\
\text { Implementation }\end{array}$ & $\begin{array}{l}\text { Very likely to be } \\
\text { implemented. } \\
\text { It takes a } \\
\text { process, especially } \\
\text { permission from the } \\
\text { foundation. }\end{array}$ & $\begin{array}{l}\text { Very likely to be } \\
\text { implemented. } \\
\text { Need Learning } \\
\text { First }\end{array}$ & $\begin{array}{c}\text { Very likely to be } \\
\text { implemented. } \\
\text { Still under } \\
\text { school consideration. }\end{array}$ \\
\hline
\end{tabular}

\section{CONCLUSION}

Based on the research results from the design of mobile applications as a medium of communication and information broadcasting for elementary school based on android, it can be concluded that the final result is the development of a mobile application as a medium of communication and information broadcasting for elementary school based on android that is beneficial for users (the school and parents of students) and makes it easier for users to obtain and send school information. In this application system, 3 features can be accessed by mobile users including the announcement feature, the test scores feature, and the message feature. This mobile application system can be downloaded via the Google Play Store with the keyword "Sekolahku".

\section{ACKNOWLEDGMENT}

This research was financially supported by Sriwijaya University, Palembang, Indonesia.

\section{REFERENCES}

[1] Miarso, Yusufhadi. Sowing the Seeds of Educational Technology (translated). Jakarta. 2005.

[2] Rizal, Hidayat. Adhy, Satriyo. Wirawan, Panji Wisnu. Designing and Making Android-Based Interactive Mobile Learning with Personal Extreme Programming Methods (translated). Jurnal Informasi dan Teknologi, 2(3):103-112. 2014.

[3] Amlani R. Comparison of Different SDLC Models. International Journal of Computer Application \& Information Technology ; Vol.II (Issue 1) : pages. 2013.

[4] Sudarma. MySQL Database Server Study Guide (translated). Jakarta Selatan: Media Kita. 2010.
[4] Alan Dennis, Barbara Haley Wixom, David Tegarden. Systems Analysis and Design with UML Version 2.0. USA: John Wiley \& Son. 2005.

[5] Abdulloh, Rohi. Easily Create Android Ionic3 Applications (translated). Jakarta: Elex Media Komputindo. 2018.

[6] Nidhra, Srinivas. dan Jagruthi Dondeti. Black Box and White Box Testing Techeniques. Internasional Journal of Embedded Systems and Applications (IJESA) Vol.2, No. 2. 2012.

[7] Pressman, R.S. Software Engineering A Practitioner's Approach. McGraw- Hill Book Co. 1997.

[8] Winarno, Edy. dan Ali Zaki. Web Programming Based on HTML 5, PHP, dan JavaScript (translated). Jakarta: PT Elex Media Komputindo. 2014. 